\title{
General Aspects Concerning New Substances with Psychoactive Properties
}

\author{
Nicoleta-Elena BUZATU \\ Faculty of Juridical and Administrative Sciences, Public Law Department, "Dimitrie Cantemir" \\ Christian University, Bucharest, Romania,E-mail:nicoleta_buzatu@yahoo.com
}

DOI: 10.6007/IJARBSS/v5-i9/1854 URL: http://dx.doi.org/10.6007/IJARBSS/v5-i9/1854

\begin{abstract}
In our country, new types of drugs appeared, that are nothing else but substances obtained from plants growing in different parts of the globe, or synthetic substances whose production serves a legal purpose, being called ethno-botanic substances or plants. The appearance of several new substances with uncontrolled psychoactive properties (SUPP) is a serious problem for the current drug control patterns. SUPP have become widely available. The fastness of their occurrence and the distribution manners hinder the existing procedures of control of their use.
\end{abstract}

Key words: Drugs, new substances, psychoactive properties, plants, ethno-botanic substances, consumption

\section{Introduction}

Along history, the drug phenomenon has had an ascending evolution, meaning that, whereas in the ancient times, drugs were used for medicinal and therapeutic purposes by the healers, in our contemporary era, they are harvested, produced and traded by criminal networks belonging to organized criminality.

The drug is a psychosocial and cultural reality that was born together with the mankind, and its origins must be sought in the ancient civilizations that were using, during their religious rituals, the smoke of the aromatic plants and of mushrooms with hallucinogen or stimulating effect, by priests or witchdoctors in order to enslave and control masses of followers.

Today, the active principles of the plants traditionally processed and used since the beginning of mankind for therapeutic purposes or in magical rituals, during religious ceremonies or only for the induced organic state of satisfaction, are obtained by chemical synthesis and their effects are even more powerful and dangerous than the plants they were extracted from (Stoian, G.M., 2013, p. 150).

The performed specialized studies have concluded that the people, especially the youth and the teenagers, are keen on trying new sensations, using new substances. Thus, drug dealers have adapted, meaning that they have searched, and found, new substances that have similar effects as classical drugs, if consumed.

Taking advantage of the fact that some of these substances are not considered as illicit in certain countries, various individuals or legal entities import and trade them without a trading license in various stores and particularly via the Internet, thus earning important profit.

This commercial name is used with the purpose to induce a positive perception about them by the society, since it is a well-known fact that the ethno-botanic plants, in this case the medicinal and aromatic plants, based on the deep knowledge of their chemical composition, of their 
pharmacodynamic properties, constitute one of the main sources of raw materials used to prepare natural products necessary to preserve the state of health. The therapeutic value of these plants is based on the relation between the chemical structure of the active substances and their synergic action that they have on the body.

In 2010, most ethno-botanic stores open particularly near schools and near the accommodation areas of students were closed, and these products were traded in various stores, such as: flower shops - as plant fertilizers, room, car deodorants, bath salt; aquarium maintenance center - as fish food; pet shop - as dog food, etc. This disguised diversity of use makes it harder to collect and interpret the data referring to "legal drug" predominance.

The operation of such stores was explained by a lack in the relevant laws, in this case by omitting to include these hallucinogen substances in the 4 tables constituting annexes for the Law no. 143/2000 on the combat of traffic and on the illicit drug consumption, with the subsequent additions and amendments and republished in 2014.

At the same time, the stores closed by the authorities were also re-opened on-line, and thus the Internet has become a great dream store. It is enough to search on Google, for instance, and one may buy ethno-botanic plants by only one click, and the stuff is delivered the second door to one's door, naturally, if one pays for it. Deliveries are usually made by fast courier services, and they may reach the destination in 1-3 days, depending on the distance and time of the order. The suspicious parcels and their senders are very hard to find. The on-line market gets involved in the potential spreading of the new psychoactive substances, and its monitoring is a more and more important element helping to identify the new drug trends.

Most suppliers of such substances have sold them in bulk, as powder, whose package says they are plant fertilizers, bath salt, frankincense, ornamental snow, etc., and not as tablets, because this would have contradicted the statement according to which they are sold for research purposes, and not for consumption. The doses of active substance vary in wide ranges from one substance to the next, departing from several micro-bodies up to hundreds of milligrams, but while it is very important for the end user to weight the doses with an analytical precision, instead of weighing them visually, many users have not done so, which has led them to the emergency rooms of hospitals and even caused their death (Costache, E.; Stoian, M.G., 2014, p. 173).

SUPP consumption may have important implications on health and public politics, and the monitoring of the emerging tendencies represents a considerable challenge. The new patterns of drug consumption are difficult to detect, as they usually appear for the first time at low levels and in specific places or within small sub-groups of population (OEDT, 2008, p. 95).

The variety and number of synthetic cannabinoids or of other substances that may be added to plant products show new challenges as regards their identification, monitoring and risk analysis. Almost nothing is known of the pharmacologic, toxicological and safety profile of these compounds on people (Jone, C.; Ştefan, C.E.; Nenov, P., 2012, p. 17).

To hide the addition of synthetic chemical compounds, the manufacturers add in the mixture a large amount of substances that show no hazard, such as vitamin E, caffeine or menthol. Also, some of the mixtures may even contain heavy metal residues, dangerous for the body.

Plants such as lavender, hypericum, parsley, rosemary, coriander etc., may become ethnobotanic plants by the technique of spraying with synthesis drugs. The ethno-botanic plants are medicinal plants, but mixed with synthesis drugs in various quantities, they become toxic, and the addiction or worse, death, results after a large consumption of a forbidden substance or due to overdoses, and not because of the plants. 
These products are particularly traded as cigarettes, tablets, powders, vegetal fragments packed in sachets, under such names as: Spice Gold, Genie, Pulse, Spice Diamond, Wild Opium Mix, Mojo, Shunk, Smoke, Hummer, Fly Agaric Mushroom etc., or famous plants such as Ergot, Keraton, Mitragyna, Sage, Morning Glory etc. As one may notice, the ethno-botanic plants include an extended range of names and physical-chemical properties. An entire chapter of mathematic probabilities may combine, move or arrange them.

This new situation is a challenge not only for the competent national structures in charge with repressing drug dealing, but also for the experts and specialists of criminal physical-chemical test laboratories, who are expected to have a quick and suitable reaction in identifying the new and unexpected drug combinations appearing on the illicit market, due to the ingenuity of clandestine producers (Stoian, M.G., 2013, p. 150).

\section{Conclusions}

The safety of the substances destined for research has not been tested yet, and very little toxicological or pharmacological research or even no research at all, has been done over many such drugs. Many of the compounds destined for research have caused unpredictable secondary effects and adverse incidents, due to the failure to check any side effects before trading them.

\section{References}

1. Costache, E.; Stoian, M.G., (2014), Noile droguri - posibile efecte ce pot conduce la accidente rutiere, Journal of Criminology, Criminalistics and Penology, no 3-4.

2. OEDT, (2008), Drug status in Europe. Annual report 2008, Luxemburg, EU Office for publications.

3. Stoian, G. M., (2013), Contribuţia expertizei fizico-chimice a probelor materiale la probaţiunea judiciară, Bucharest, Romanian Association of Criminalists.

4. Tone, C.; Ştefan, C.E.; Nenov, P., (2012) „Etnobotanicele” vise care ucid, Craiova, SITECH Publishing House. 